\title{
KEBIJAKAN DAN PELAYANAN PEMBIAYAAN MURABAHAH TERHADAP TINGKAT KEPUASAN NASABAH
}

\section{Mujizatullah}

Balai Penelitian dan Pengembangan Agama Makassar || mujizatullah@kemenag.go.id

\begin{abstract}
Abstrak
Jenis penelitian ini merupakan penelitian kuantitatif yang dilakukan di PT. Bank Sulselbar Syariah. Penelitian ini termasuk penelitian kuantitatif yang bertujuan untuk mengetahui pengaruh pelayanan pembiayaan Murabahah terhadap tingkat kepuasan nasabah pada PT. Bank Sulselbar Syriah Cabang Makassar. Dalam penelitian ini terdiri dari tiga variabel, yaitu PT. Bank Sulselbar sebagai $\mathrm{X}_{1}$, pelayanan pembiayaan Murabahah sebagai $\mathrm{X}_{2}$, dan tingkat kepuasan nasabah sebagai Y.

Total Sampling dalam penelitian ini berjumlah 75 orang. Untuk gambaran pemgaruh pelayanan pembiayaan Murabahah, peneliti menggunakan lembar observasi dan wawancara bebas dan angket pada nasabah dan karyawan PT. Bank Sulselbar Cabang Makassar. Selanjutnya, data yang diperoleh melalui instrument tersebut kemudian diolah dengan bantuan aplikasi Partial Least Square (PLS) 2.0

Hasil penelitian menunjukkan bahwa hasil analisis yang menggunakan uji $t$ menunjukkan bahwa nilai $t_{\text {hitung }}$ lebih kecil dari pada nilai $t_{\text {table }}$ sehingga Ho diterima dan Ha diterima. Artinya pelayanan pembiayaan murabahah berpengaruh terhadap tingkat kepuasan nasabah pada PT. Bank Sulselbar Syariah Makassar.
\end{abstract}

Kata Kunci: Kebijakan, Pelayanan, Pembiayaan Murabahah, Kepuasan Nasabah 


\begin{abstract}
This type of research is a quantitative research conducted at Bank Sulselbar Ltd.Company Makassar Sharia Branch. This research includes quantitative research that aims to determine the effect of Murabahah financing services on the level of customer satisfaction at Bank Sulselbar Ltd.Company Makassar Sharia Branch Office. In this study consists of three variables, namely Ltd.Company Bank Sulselbar as X1, Murabahah financing service as $X 2$, and customer satisfaction level as $Y$.

Total Sampling in this research amounted to 75 people. To illustrate the influence of Murabahah financing service, the researcher uses observation sheets and free interviews and questionnaires to customers and employees of Bank Sulselbar Ltd.Company Makassar Sharia Branch Office. Furthermore, the data obtained through the instrument is then processed with the help of Partial Least Square (PLS) 2.0 application

The results showed that the results of analysis using $t$ test showed that the value of $t_{\text {arithmetic }}$ smaller than the value of $t_{\text {table }}$ so $H_{0}$ accepted and $H_{a}$ accepted. It means service murabahah financing affects the level of customer satisfaction at Ltd.Company Bank Sulselbar Makassar.
\end{abstract}

Keywords: Murabaha service, customer satisfaction

\section{PENDAHULUAN}

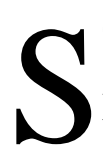

ejak awal kelahirannya, perbankan syariah dilandasi dengan kehadiran dua gerakan renaissance islam modern, neorevivalis dan modernis. Tujuan utama dari pendirian lembaga keuangan berlandaskan etika ini adalah tiada lain sebagai upaya kaum muslimin untuk mendasari segenap aspek kehidupan ekonominya yang berlandaskan Al-Qur'an dan AsSunnah.

Dalam undang-undang No. 20 Tahun 2008 tentang perbankan syariah disebutkan dalam pasal 1 bahwa perbankan syariah adalah segala sesuatu yang menyangkut tentang bank syariah dan unit usaha syariah , mencakup kelembagaan, kegiatan usaha, serta cara dan proses dalam melaksanakan kegiatannya.

Undang-undang tersebut menjadi landasan hukum dalam dunia perbankan untuk mendirikan beberapa lembaga perbankan syariah. Salah satunya adalah Bank Sulselbar mendirikan divisi atau unit perbankan syariah yang terbesar dibeberapa wilayah di Sulawesi Selatan. Bank

2 | Kebijakan dan Pelayanan Pembiayaan Murabahah terhadap Tingkat Kepuasan Nasabah 


\section{J-HES}

Jurnal Hukum Ekonomi Syariah

Volume 2 | Nomor 1 | Januari-Juni 2018 | ISSN: 2549-4872

Sulselbar Syariah Cabang produk yang ditawarkan. Nasabah Makassar merupakan salah satu yang dihadapi saat ini berbeda dengan bukti eksistensi perbankan syariah nasabah pada tahun-tahun yang lalu, di Indonesia, khususnya di kini nasabah semakin terdidik dan Sulawesi Selatan.

Bank Sulselbar Syariah Cabang Makassar adalah salah satu lembaga keuangan syariah sebagai intermediasi keuangan, merupakan tempat terjadinya lalulintas uang dan dokumen-dokumen berharga lainnya. Salah satu kegiatannya yaitu menghimpun dan menyalurkan kembali dana tersebut melalui pembiayaan guna memperoleh pendapatan yang juga akan dibayarkan kepada nasabah sebagai bagi hasil pengelolaan dana.

Harapan nasabah umumnya merupakan perkiraaan atau keyakinan nasabah tentang apa yang akan diterimanya bila ia memakai suatu (barang atau jasa) dalam pembiayaan. Sedangkan kinerja yang dirasakan adalah persepsi nasabah terhadap apa yang ia terima setelah memakai sesuatu.

Meskipun demikian tidaklah mudah untuk mewujudkan kepuasan nasabah secara menyeluruh kepada menyadari hak-haknya. Oleh karena itu dapatlah dipahami bahwa tidak realistis bila suatu lembaga usaha mengharapkan pelayanan yang baik sementara nasabah tidak puas akan kinerja dan yang ia tawarkan.

Menurut Kotler

(1997),

kepuasan adalah perasaan seseorang menyangkut kenyamanan atau kekecewaan sebagai akibat dari perbandingan antara kinerja (outcome) produk yang dipersepsikan dalam kaitannya dengan harapan. Jadi apakah pembeli puas setelah membeli adalah tergantung pada kinerja yang ditawarkan dalam hubungannya dengan terpenuhi tidaknya harapan pembeli.

Secara umum kepuasan adalah perasaan senang atau kecewa seseorang yang muncul setelah membandingkan kinerja (hasil) produk yang dipikirkan terhadap kinerja (hasil) yang diharapkan.

Menurut kotler pelayanan adalah setiap tindakan atau pelayanan yang 
dapat ditawarkan oleh suatu pihak dalam melaksanakan kegiatan kepada pihak lain, yang pada usahanya.

dasarnya tidak terwujud dan tidak mengakibatkan kepemilikan apapun.

Pelayanan yang berkualitas adalah apabila yang dikerjakan seseorang untuk orang lain menimbulkan rasa tentram dan bahagia yang memberikan implementasi erat tali silaturrahmi antara kedua bela pihak yang bersangkutan dengan terjadinya silaturrahmi maka dapat meluangkan rezki dan memanjangkan usia.

Menurut Zeithalm dalam Fajar Laksana (2008:88) kemukakan bahwa kualitas pelayanan yang diterima konsumen dinyatakan besarnya perbedaan antara harapan dan keinginan konsumen dengan tingkat persepsi mereka.

Dalam undang-undang No. 20 Tahun 2008 tentang perbankan syariah disebutkan dalam pasal 1 bahwa "perbankan syariah adalah segala sesuatu yang menyangkut tentang bank syariah dan unit usaha syariah, mencakup kelembagaan kegiatan usaha, serta cara dan proses Bank syariah adalah bank yang aktifitasnya meninggalkan masalah riba. Bank syariah adalah institusi keuangan yang berbasis syariah islam. Hal ini berarti bahwa secara makro bank syariah adalah institusi keuangan yang memposisikan dirinya sebagai pemain aktif dalam mendukung dan memainkan kegiatan investasi di masyarakat sekitarnya. Di satu sisi bank syariah adalah lembaga keuangan yang mendorong dan mengajak masyarakat untuk ikut aktif berinvestasi melalui berbagai produknya, sedangkan disisi lain bank syariah aktif untuk melakukan investasi di masyarakat.

Murabahah yaitu persetujuan jual-beli suatu barang dengan harga sebesar harga pokok ditambah dengan keuntungan yang disepakati bersama dengan pembayaran ditangguhkan 1 bulan sampai 1 tahun.

Selanjutnya menurut Asro dan Khoiid (2011:71) mengatakan bahwa Murabahah merupakan kegiatan jual be!i pada harga pokok dengan 


\section{J-HES}

Jurnal Hukum Ekonomi Syariah

Volume 2 | Nomor 1 | Januari-Juni 2018 | ISSN: 2549-4872

tambahan keuntungan yang disepakati.

Dalam hal ini penjual harus terlebih dahulu memberitahukan harga pokok yang ia beii ditambah kentungan yang inginkan.

Al-Murabahah adalah jual beli barang dengan harga asal dengan tambahan keuntungan yang disepakati. Dalam bai' AlMurabahah, penjual (dalam hal ini adalah bank) harus memberi tahu harga produk yang dibeli dan menentukan tingkat keuntungan sebagai tambahannya. Saat ini, produk inilah yang paling banyak digunakan oleh bank syariah karena paling mudah dalam implementasinya dibandingkan dengan produk pembiayaan lainnya.

Dalam hadits disebutkan riwayat dari Abu Said al-Khudri bahwa Rasulullah bersabda: "Sesungguhnya jual beli itu harus dilakukan suka sama suka". (H.R. AlBaihaki dan Ibnu Majah). Sabda yang lain: " Ada tiga hal yang mengandung berkah, jual beli tidak secara tunai, muqaradhah (mudharabah) dan mencampur gandum dengan jewawat untuk keperluan rumah tangga, bukan untuk dijual”. (HR. Ibnu Majah).
Hadits diatas memberikan prasyarat bahwa akad jual beli Murabahah harus dilakukan dengan adanya kerelaan masing-masing pihak ketika melakukan transaksi. Segala ketentuan yang terdapat jual beli beli Murabahah, seperti penetuan harga jual, margin yang diinginkan, mekanisme pembayaran, dan lainnya, harus terdapat persetujuan dan kerelaan antara pihak nasabah dan bank, tidak bisa ditentukan secara sepihak.

\section{METODE PENELITIAN}

Secara umum populasi dapat diartikan sebagai keseluruhan objek penelitian yang didalamnya mencakup semua elemen-elemen yang terdapat dalam wilayah tentorial penelitian tersebut dilaksanakan. Berdasarkan pengertian tersebut maka adapun populasi dari penelitian ini adalah nasabah pada PT. Bank Sulselbar Syariah Cabang Makassar yang berjumlah 300 orang. Jadi sampel dalam penelitian ini berjumlah 75 orang nasabah.

Penelitian ini menggunakan metode kuantitatif dengan pendekatan deskriptif dimana peneliti berusaha 
untuk menuturkan pemecahan masalah yang berdasarkan data-data, sehingga peneliti juga menyajikan data, menganalisis dan menginterpretasi.

Peneliti melakukan pengamatan, mengamati gejala dan mencatat dalam buku observasi. Dengan suasana demikian sehingga peneliti terjun langsung kelapangan. Peneliti mencari jawaba terhadap rumusan masalah yang diteliti dengan menyesuaikan pada kondisi lingkungan penelitian yang natural.

Jenis data: 1) Data kualitatif adakah data yang diperoleh dengan cara melakukan penelitian yang menghasilkan data deskriptif analisis, yaitu apa yang dinyatakan responden secara tertulis atau lisan mengenai tingkat kepuasan nasabah terhadap pelayanan produk pembiayaan rnurabahah. 2) Data kuantitatif adakah data yang diperoleh berupa angkaangka yang berhubungan dengan penelitian ini.

Sumber data untuk penelitian ini diperoleh dari: 1) Data primer, ialah data yang diperoleh dari hasil wawancara terhadap pihak-pihak yang dianggap perlu untuk diambil keterangannya mengenai masalahmasalah yang akan dibahas dalam penelitian ini. 2) Data sekunder, ialah data yang diperoleh melalui studi kepustakaan pada buku-buku, artikel, karya ilmiah yang berhubungan dengan pembahasan skripsi ini.

Analisis data dilakukan dengan cara analisis kuantitatif dengan menggunakan metode Partial Least Square (PLS), yaitu suatu metode yang berbasis keluarga regresi yang dikenalkan oleh Herman O.A Wold untuk penciptaan dan pembangunan model dan metode untuk ilmu - ilmu sosial dengan pendekatan yang berorientasi pada prediksi. PLS memilki asumsi data penelitian bebas distribusi (Distribution - Free), artinya data penelitian tidak mengacuh pada salah satu distribusi tertentu (misalnya distribusi normal). PLS merupakan metode alternative dari Structural Equation Modeling (SEM) yang dapat digunakan untuk mengatasi permasalahan hubungan diantara variabel yang kompleks namun ukuran sampel datanya kecil (30 sampai 100), 


\section{J-HES}

Jurnal Hukum Ekonomi Syariah

Volume 2 | Nomor 1 | Januari-Juni 2018 | ISSN: 2549-4872

mengingat SEM memilki ukuran konstrak endogen merupa-kan konstrak sampel data minimal (Hair et.al., yang dijelaskan oleh konstrak 2010). PLS digunakan untuk eksogen. Konstrak endogen adalah mengetahui kompleksitas hubungan efek dar konstrak eksogen (Yamin dan suatu kontsrak dan konstrak yang lain, Kurniawan, 2009). PLS dapat bekerja serta hubungan suatu konstrak dan untuk model hubungan konstrak dan indikator - indikatornya. PLS indikator - indikatornya yang didefenisikan oleh dua persamaan, bersifat reflektif dan formatif, yaitu inner model dan outer model. sedangkan SEM hanya bekerja pada Inner model menentukan spesifikasi model hubungan yang bersifat reflektif hubungan antara suatu konstrak dan saja.

konstrak yang lain, sedangkan outer model menentukan spesifikasi hubungan antara konstrak dan indikator - indikatornya. Konstrak terbagi menjadi dua yaitu konstrak eksogen dan konstrak endogen. Konstrak eksogen merupakan konstrak penyebab, konstrak yang tidak dipengaruhi oleh konstrak lainnya. Konstrak eksogen memberi-kan efek kepada konstrak lainnya, sedangkan

\section{HASIL PENELITIAN}

Metode analisis yang digunakan dalam penelitian ini adalah analisis yang diperoleh dari Pengaruh Pelayanan Pembiayaan Murabahah Terhadap Tingkat Kepuasan Nasabah Pada PT.Bank Sulselbar Syariah Makassar dan diolah dengan menggunakan model Smart PLS 2.0

Tabel 1

Kebijakan PT. Bank Susebar Syariah $(\xi)$

Penyataan Responden

\begin{tabular}{lllllll} 
No & \multicolumn{1}{c}{ Indikator } & 5 & 4 & 3 & 2 & 1 \\
\hline 1 & $\mathrm{X}_{1}$ (Prinsip syariah) & 44 & 30 & 1 & - & - \\
\hline 2 & $\mathrm{X}_{2}$ (Produk) & 39 & 36 & - & - & - \\
\hline 3 & $\mathrm{X}_{3}$ (Margin) & 42 & 33 & - & - & - \\
\hline 4 & $\mathrm{X}_{4}$ (Nasabah) & 28 & 47 & - & - & - \\
\hline
\end{tabular}


Kesimpulan:

$\mathrm{X}_{1}=$ untuk Indikator (Prinsip syariah) yang memiliki kategori sangat setujuh sebanyak 44. Indikator ini mampu memengaruhi variable kebijakan.

$\mathrm{X}_{2}=$ untuk Indikator (Produk) yang memiliki kategori sanagat setujuh sebanyak 39. Indikator ini mampu memengaruhi Variabel kebijakan
$\mathrm{X}_{3}=$ untuk Indikator (Margin) yang memiliki kategori sangat setujuh sebanyak 42. Indikator ini mampu memengaruhi variabel kebijakan.

$\mathrm{X}_{4}=$ untuk Indikator (Nasabah) yang memiliki kategori setujuh sebanyak 47. Indikator ini mampu memengaruhi variabel kebijakan.

Tabel 2

Pelayanan pembiayaan Murabahah (o)

\begin{tabular}{llccccc}
\hline & & \multicolumn{7}{c}{ Penyataan Responden } \\
\cline { 3 - 7 } No & Indikator & 5 & 4 & 3 & 2 & 1 \\
\hline 1 & $\mathrm{X}_{5}$ (Tangibles) & 37 & 38 & - & - & - \\
\hline 2 & $\mathrm{X}_{6}$ (Reliability) & 31 & 43 & 1 & - & - \\
\hline 3 & $\mathrm{X}_{7}$ (Responsiveness) & 24 & 49 & 2 & - & - \\
\hline 4 & $\mathrm{X}_{8}$ (Assurance) & 30 & 40 & - & - & - \\
\hline 5 & $\mathrm{X}_{9}$ (Empaty) & 24 & 51 & - & - & - \\
\hline
\end{tabular}

Kesimpulan:

$\mathrm{X}_{5}=$ untuk Indikator (Tangibles) yang memiliki kategori setujuh sebanyak 38. Indikator ini mampu memengaruhi variable pelayanan pada pembiayaan Murabahah.
$\mathrm{X}_{6}=$ untuk Indikator (Reliability) yang memiliki kategori setujuh sebanyak 43. Indikator ini mampu memengaruhi Variabel pelayanan pada pembiayaan Murabahah

$\mathrm{X}_{7}=\quad$ untuk Indikator

(Responsiveness) yang memiliki kategori setujuh sebanyak 49. 


\section{J-HES}

Jurnal Hukum Ekonomi Syariah

Volume 2 | Nomor 1 | Januari-Juni 2018 | ISSN: 2549-4872

Indikator ini mampu pelayanan pada pembiayaan

memengaruhi variabel pelayanan

Murabahah.

pembiayaan Murabahah.

$\mathrm{X}_{9}=$ untuk Indikator (Empaty) yang

$\mathrm{X}_{8}=$ untuk Indikator (Assurance)

memiliki kategori setujuh

yang memiliki kategori setujuh

sebanyak 40. Indikator ini

sebanyak 51. Indikator ini

mampu memengaruhi variabel

mampu memengaruhi variabel pelayanan pada pembiayaan

Murabahah.

Tabel 3

Tingkat kepuasan nasabah $(\beta)$

\begin{tabular}{llrrrrr}
\hline No & \multirow{2}{*}{ Indikator } & \multicolumn{5}{c}{ Penyataan Responden } \\
\cline { 3 - 7 } & & 5 & 4 & 3 & 2 & 1 \\
\hline 1 & \multirow{2}{*}{$\mathrm{Y}_{1}$ (Kualitas produk) } & 42 & 33 & - & - & - \\
\hline 2 & $\mathrm{Y}_{2}$ (Kualitas pelayanan) & 21 & 52 & 2 & - & - \\
\hline 3 & $\mathrm{Y}_{3}$ (Emosi) & 22 & 52 & 1 & - & - \\
\hline 4 & $\mathrm{Y}_{4}$ (Biaya) & 28 & 47 & - & - & -
\end{tabular}

Kesimpulan:

$\mathrm{Y}_{1}=$ untuk Indikator (Kualitas produk)

yang memiliki kategori sangat

setujuh sebanyak 42. Indikator

ini mampu memengaruhi variable

tingkat kepuasan nasabah.

$\mathrm{Y}_{2}=$ untuk Indikator (Kualitas pelayanan) yang memiliki

kategori setujuh sebanyak 52 .

Indikator ini mampu memengaruhi Variabel tingkat

kepuasan nasabah.

$\mathrm{Y}_{3}=$ untuk Indikator (Emosi) yang memiliki kategori setujuh sebanyak 52. Indikator ini mampu memengaruhi variabel tingkat kepuasan nasabah.

$\mathrm{Y}_{4}=$ untuk Indikator (Biaya) yang memiliki kategori setujuh sebanyak 47. Indikator ini 
mampu memengaruhi variabel tingkat kepuasan nasabah.

\section{Uji Validasi dan Reliability}

Diperoleh nilai validasi dan reliability digunakan composite reliability dengan nilai diatas 0,5 $(>0,5)$ kebijakan PT. Bank Sulselbar Syariah $0,4803<0,5$ akan tetapi angka tersebut cukup ekuivaen dengan 0,5, jadi data tersebut cukup reliability. Untuk nilai validasi digunakan Cronback Alpha dengan nilai $(0,5)$ digunakan $0,2443<0,5$ tidak valid. Pelayanan pembiayaan Murabahah $0,5862>0,5$ jadi data tersebut reliability. Untuk nilai validasi digunakan Cronbac Alpha dengan nilai $(0,5)$ digunakan $0,3924>0,5$ tidak valid. Tingkat kepuasan nasabah nilai $0,4715<0,5$ jadi data cukup reliability. Untuk nilai validasi digunakan Cronback Alpha dengan nilai $(0,5)$ digunakan 0,5848>0,5 valid.

Measurement Model Specification adalah pengukuran :

1. Mean $\left(\mathrm{rata}^{2}\right)$ hasil indifiction yang terdiri dari $\mathrm{X}_{1}$ sampai dengan $\mathrm{X}_{4}$ untuk variabel kebijaka, $\mathrm{X}_{5}$ sampai dengan $\mathrm{X}_{9}$ untuk variabel pelayanan pembiyaan Murabahah, dan $\mathrm{Y}_{1}$ sampai dengan $\mathrm{Y}_{4}$ untuk variabel tingkat kepuasan nasabah adalah terlihat dari olah data menunjukkan pada variabel kebijakan adalah $\mathrm{X}_{1} \operatorname{rata}^{2}>4, \mathrm{X}_{2}$ $\operatorname{rata}^{2}>4, \mathrm{X}_{3} \operatorname{rata}^{2}>4, \mathrm{X}_{4} \operatorname{rata}^{2}>$ 4. Pada variable pelayanan pembiyaan Murabahah adalah $\mathrm{X}_{5}$ $\operatorname{rata}^{2}>4, \mathrm{X}_{6} \mathrm{rata}^{2}>4, \mathrm{X}_{7} \mathrm{rata}^{2}>$ $4, \mathrm{X}_{8} \operatorname{rata}^{2}>4, \mathrm{X}_{9} \operatorname{rata}^{2}>4$. Sedangkan pada variable tingkat kepuasan nasabah adalah $\mathrm{Y}_{1}$ rata $^{2}$ $>4, \mathrm{Y}_{2} \operatorname{rata}^{2}>4, \mathrm{Y}_{3} \operatorname{rata}^{2}>4$, $\mathrm{Y}_{4} \mathrm{rata}^{2}>4$.

2. Manifest di variabel kebijakan telah diukur dari $\left(\mathrm{X}_{1}\right.$ sampai dengan $\left.\mathrm{X}_{4}\right)$ dan variable pelayanan pembiayaan Murabahah telah diukur dari ( $\mathrm{X}_{5}$ sampai dengan $\mathrm{X}_{9}$ ) dan variabel tingkat kepuasan nasabah telah diukur dari $\left(\mathrm{Y}_{1}\right.$ sampai dengan $\mathrm{Y}_{4}$ ). 


\section{J-HES}

Jurnal Hukum Ekonomi Syariah

Volume 2 | Nomor 1 | Januari-Juni 2018 | ISSN: 2549-4872

3. Model Specification pelayanan pembiayaan memiliki (Konstrak) terdiri dari 3 korelasi dengan variabel tingkat variabel, masing-masing kepuasan nasabah ebesar $\mathrm{t}_{\text {hitung }} 0,6378$ variabel kebijakan, variabel pelayanan Murabahah dan variabel tingkat kepuasan.

Hipotesis 1: diduga variabel kebijakan PT. Bank Sulselbar Syariah berpengaruh terhadap pelayanan pembiayaan Murabahah.

Hasil pengujian outer model yang telah dilakukan menunjukkan bahwa hubungan antara variable. Kebijakan PT. Bank Sulsebar Syariah memiliki korelasi dengan variabel pelayanan pembiayaan Murabahah sebesar $t_{\text {hitung } 1}, 0729<t_{\text {tabel }} 1,665$ menunjukkan bahwa pada hipotesis 1 diterima . Diartikan bahwa variabel Kebijakan PT. Bank Sulsebar Syariah berpengaruh signifikan terhadap variabel pelayanan pembiayaan Murabahah.

Hipotesis 2: diduga variabel pelayanan pembiayaan Murabahah berpengaruh terhadap variabel tingkat kepuasan nasabah.

Hasil pengujian outer model yang telah dilakukan, menunjukkan bahwa hubungan antara variabel $<\mathrm{t}_{\text {tabel }} 1,665$ menunjukkan bahwa pada hipotesis 2 diterima karena variabel pelayanan pembiayaan Murabahah berpengaruh signifikan terhadap variabel tingkat kepuasan nasabah.

Hipotesis 3: diduga variabel kebijakan PT. Bank Sulselbar Syariah berpengaruh terhadap variabel tingkat kepuasan nasabah

Hasil pengujian outer model yang telah dilakukan menunjukkan bahwa hubungan antara variabelPT. Bank Sulselbar Syariah memiliki korelasi antara variabeltingkat kepuasan nasabah sebesar menunjukkan bahwa $t_{\text {hitung }} 2,7685>t_{\text {tabel }} \quad 1,665$ menunjukkan bahwa pada hipotesis 3 ditolak. Diartikan bahwa variabel kebijakan PT. bank sulselbar syariah tidak memiliki pengaruh yang signifikan terhadap variabel tingkat kepuasan nasabah.

\section{KESIMPULAN}

Kebijakan PT. Bank Sulselbar Syariah berpengaruh terhadap pelayanan pembiayaan Murabahah. Hasil pengujian outer model yang telah dilakukan menunjukkan bahwa 
variable kebijakan PT. Bank Sulselbar Syariah dapat mempengaruhi pelayanan pembiayaan Murabahah pada bank tersebut.

Pelayanan pada pembiayaan murabahah berpengaruh terhadap tingkat kepuasan nasabah. Hasil pengujian outer model yang telah dilakukan menunjukkan bahwa variable Pelayanan pembiayaan murabahah dapat mempengaruhi tingkat kepuasan nasabah pada bank tersebut.

Kebijakan PT. Bank Sulselbar Syariah berpengaruh terhadap Tingkat kepuasan nasabah. Hasil pengujian outer model yang telah dilakukan menunjukkan bahwa variabel. Kebijakan PT. Bank Sulselbar Syariah tidak dapat mempengaruhi tingkat kepuasan nasabah pada bank tersebut.

\section{DAFTAR PUSTAKA}

Alam Buchari. Manajemen Pemasaran dan Pemasaran Jasa. Bandung Alfabet, 2007.

Antonio, M. Syafii. Bank Syariah dari Teori ke Praktek. Cet. I; Jakarta Gema Insani, 2001.

Ascarya. Akad dan Produk Bank Syariah. Jakarta: Raja grafindo Persada,2008.

Asro, M, dan Kholid, M. Fiqih Perbankan. Cet. I; Bandung: Pustaka Setia,2011.

Ali Muhammad. Penelitian Pendidikan Prosedur dan Strategi. Bandung: PT.Aksara, 1985.

Awaluddin. Manajemen Bank Syariah. Makassar: Alauddin University Press,2011.

Departemen Agama Republik Indonesia, Al-Quran dan Terjemahnya, Bandung: PT. Sygma Examedia Arkanleema, 2009.

Hasan. M. Iqbal. Pokok-Pokok Materi Statistika. Get, I; Jakarta: Aksara, 1999. Indonesia

Bank. Perbankan Syariah Lebih dari Sekedar Bank. Jakarta: Bank Indonesia, 2009.

Sumitro, Warkum. Asas-Asas Perbankan Islam dan Lembaga Terkait BMI dan Takaful di Indonesia. Jakarta: Raja Grafindo Persada, 2002. 


\section{J-HES}

Jurnal Hukum Ekonomi Syariah

Volume 2 | Nomor 1 | Januari-Juni 2018 | ISSN: 2549-4872

Kotler Philip dan Kevin Lane Keller. Manajemen Pemasaran. Jakarta Indeks, 2009.

Kasmir. Dasar-Dasar Perbankan. Jakarta: PT Raja Grafindo. 2003

Laksana Fajar. Manajemen Pemasaran. Yogyakarta; Graha Ilmu, 2008

Muhammad. Manajemen Dana Bank Syariah. Cet, II; Yogyakarta: Ekonisia. 2005.

Nawawi Ismail. Ekonomi Islam,Perspektif Teori, Sistem, dan Aspek Hukum. Surabaya: Putra Media Nusantara, 2009

Nawawi, Hadari. Metodologi Penelitian Bidang Sosial. Cet.VI; Yogyakarta: University Pers, 1993.

Soemitra, Andri. Bank dan Lembaga Keuangan Syariah. Cet. II; Jakarta: Kencana, 2010.

Wirdyaningsih, dkk.Bank dan Asuransi Islam di Indonesia.Cet, III; Jakarta: Kencana, 2005.

Yousda, Ine I Amirman.Peneiitian dan Statistik Pendidikan.Cet, I; Jakarta: Bumi Aksara, 1993.

Steel Robert G.D, H. Torrie James, Prinsip dan Prosedur Statistika (Suatu Pendekatan Biometrik).Jakarta:PT. Gramedia pustaka utama, 1995 